\title{
TEPUNG KELAPA SEBAGAI SUBSTITUEN PARSIAL DALAM PEMBUATAN WHITE BREAD
}

\author{
COCONUT FLOUR AS PARTIAL SUBSTITUENTS IN MAKING OF \\ WHITE BREAD
}

Nova Kumolontang

Balai Riset dan Standardisasi Industri Manado

Jalan Diponegoro No.21-23

Pos-el :patranovaku@gmail.com

Diterima Tanggal 27-10-2014, Disetujui Tanggal 8-11-2014

\begin{abstract}
ABSTRAK
Tepung kelapa merupakan hasil proses dari daging kelapa, mengandung lemak, protein dan serat. Tepung yang mengandung serat dapat diolah menjadi makanan fungsional seperti pada substitusi composite flour menjadi white bread. Tujuan penelitian ini adalah mencari formula campuran tepung terigu dengan tepung kelapa dalam pembuatan "white bread" yang berkwalitas dan dapat digunakan sebagai pangan fungsional serta memenuhi selera konsumen. Penelitian ini dilaksanakan menggunakan metode deskriptif dengan perlakuan pengunaan tepung kelapa $0,5,10,15,20$, dan 25\%. Analisis dilakukan secara kwantitatif dalam bentuk tabelaris. Dari hasil penelitian yang dilakukan ternyata daya kembang roti tawar yang baik diperoleh dari penggunaan 10\% dan 15\% tepung kelapa. Hasil analisis komposisi kimia roti tawar menunjukkan bahwa kadar air 31,29-32,75, lemak 5,76-9,16, protein 8,32-8,96, karbohidrat 36,64-42,16 dan serat kasar 0,81-1,79. Semakin tinggi konsentrasi tepung kelapa terjadi penurunan kadar karbohidrat, sedangkan kadar lemak, kadar serat dan kadar protein cenderung mengalami peningkatan. Dari pengujian organoleptik terhadap rasa, bau, warna, penampakan dan tekstur ternyata roti tawar yang dihasilkan disukai panelis.
\end{abstract}

Kata kunci : Tepung kelapa, roti tawar

\section{ABSTRACT}

Coconut flour is made from coconut flesh comprising fat, protein and fiber. Coconut flour which contains fibers can be used in making functional food like white bread. The purpose of this research is to find a formula of flour and coconut flour mixture in making white bread as a functional food which meet consumer preference. This study was conducted using descriptive method where the treatment were $0 \%, 5 \%, 10 \%, 15 \%, 20 \%$, and $25 \%$ of coconut flour. Quantitative analysis method using tables was carried out. The results showed that the best flower power of white bread was obtained by using of 10 and $15 \%$ of coconut flour. Results analysis showed that chemical composition of white bread (moisture, fat, protein, carbohydrate and crude fiber) were $31.29-32.75 \%, 5.76-9.16 \%, 8.32-8.96 \%, 36.64-42.16 \%$ and $0.81-1.79 \%$. An increase in the concentration of coconut flour caused a decrease in the levels of carbohydrates, while the fat content, fiber content and protein content tends to increase. Through organoleptic taste, odor, color, appearance and texture of the resulting bread were preferred by panelists.

Keywords: coconut flour, white bread.

\section{PENDAHULUAN}

Kebutuhan pangan dalam negeri tidak lepas dari persoalan beras dan terigu. Pola makan penduduk di beberapa wilayah khususnya di perkotaan cenderung berbasis terigu karena bahan makanan yang mengandung terigu lebih adaptif dan adobtif dari pada pangan domestik. Hal ini dapat dilihat dari kebiasaan menyantap 
makanan berbahan dasar tepung terigu seperti mie, kue, roti, dan lain-lain.

Kecenderungan menyantap makanan mengandung karbohidrat tinggi dan kurang serat mengakibatkan terjadinya berbagai ketidakseimbangan dalam tubuh seperti obesitas, sukar buang air besar dan lain-lain. Untuk itu perlu dicari alternative sebagai salah satu bentuk pendekatan dalam menggunakan tepung yang mengandung serat yang nantinya dapat diolah menjadi makanan yang dapat dikategorikan sebagai fungsional food (makanan fungsional).

Salah satu bahan pangan yang dapat dijadikan tepung dan mengandung serat adalah kelapa. Kelapa merupakan bagian dari kehidupan masyarakat Sulawesi Utara. Berdasarkan data dari Badan Pusat Statistik Sulawesi Utara sampai tahun 2012 produksi kelapa sebesar 272.481 ton/tahun (1). Untuk itu perlu adanya deversifikasi dalam rangka pengembangan pengolahan kelapa diantaranya dalam pemanfaatan tepung kelapa.

Tepung kelapa (desiccated coconut) adalah daging buah kelapa yang dikeringkan, dihaluskan dan diproses dibawah kondisi yang higienis untuk konsumsi manusia. Desiccated coconut mengandung minyak dan protein, dan diproduksi dalam 4 standard mutu yaitu : sangat halus, halus, sedang dan kasar dan dalam berbagai bentuk potongan termasuk “Threads, Strips, Chips, Slices dan Shreps. Penggunaan desiccated coconut terutama adalah untuk industri kembang gula dan roti. Dengan cara pressing, dapat dipisahkan dan dihasilkan tepung dan minyak yang jernih serta bermutu tinggi. Tepung ini dihasilkan dengan sistim pabrikasi dapat digunakan secara langsung untuk dijadikan bahan pangan, misalnya dicampur pada pembuatan roti (2).

Dari suatu hasil evaluasi di Philipina memperlihatkan bahwa tepung kelapa dalam jumlah yang sama dapat menggantikan fungsi tepung gandum dan susu bubuk tanpa lemak (3). Tepung kelapa biasanya dihasilkan oleh pabrikasi, namun dapat pula dibuat dengan cara pemarutan dan penghalusan menghasilkan kelapa parut kering. Rindengan menyatakan bahwa kelapa parut kering adalah bahan baku yang banyak digunakan dalam pengolahan berbagai macam biskuit, roti atau jenis kue tertentu sehingga fungsinya sebagai substitusi penggunaan tepung. Dengan demikian, maka kelapa parut kering harus memiliki sebagian dari sifat-sifat tepung, antara lain tidak lengket (bergumpal) dan berwarna putih.

"Composite Flour" atau tepung campuran adalah campuran antara komoditi non terigu (misalnya palawija, tepung ikan, tepung kelapa) dengan tepung terigu dan dapat diolah dalam berbagai macam makanan.

Teknologi Composite Flour (tepung campuran) dalam pembuatan white bread tampaknya cukup prospektif sebagai pendorong diversifikasi pangan. Pendekatan ini tentu saja tidak sesederhana yang dibayangkan melainkan tetap memerlukan berbagai pengkajian. Karena "Composite Flour" antara tepung terigu dan tepung kelapa akan membawa konsekwensi perubahan mutu white bread yang dihasilkan. Hal ini dimaksudkan agar 
dapat menghasilkan produk berupa white bread yang merupakan suatu solusi sebagai makanan fungsional. White bread adalah roti putih yang dibuat dari tepung terigu kuat (yaitu tepung yang mampu menyerap air dalam jumlah besar) serta bahan tambahan lainnya yang dapat mencapai konsistensi adonan yang tepat serta memiliki elastisitas yang baik.

Adapun tujuan dari penelitian ini adalah mencari formula campuran tepung terigu dengan tepung kelapa dalam pembuatan white bread yang bekualitas dan dapat digunakan sebagai pangan fungsional serta memenuhi selera konsumen.

\section{BAHAN DAN METODE}

\section{Bahan dan Alat}

Bahan-bahan yang digunakan dalam penelitian ini adalah tepung kelapa, tepung terigu, ragi Saccharomices cereviseae, gula, garam, bread improver, margarin, telur, air serta bahan kimia untuk analisis. Peralatan yang digunakan dal;am penelitian ini adalah : alat penggiling, alat pengepres, alat pencampur adonan, oven. Sedangkan peralatan pendukung terdiri dari erlenmeyer, gelas piala, tanur, labu khedall, serta peralatan lainnya untuk analisis kimia.

\section{Metode Penelitian}

Penelitian ini dilaksanakan menggunakan metode deskriptif secara kwantitatif dengan perlakuan pengunaan tepung kelapa $0,5,10,15,20$, dan $25 \%$.

\section{Prosedur Percobaan}

\section{a. Penyiapan Tepung Kelapa}

Tepung kelapa (kelapa parut kering) yang telah dikeringkan, dipres untuk mengeluarkan minyak dari tepung kelapa, menghasilkan tepung kelapa yang masih mengandung kadar lemak rendah. Selanjutnya dilakukan penggilingan dan pengayakan agar diperoleh tepung kelapa yang halus. Tepung kelapa yang sudah halus dikemas dengan kantong plastik.

\section{b. Pembuatan Roti}

Bahan berupa tepung terigu, tepung kelapa ditimbang sesuai perlakuan, ragi, telur, gula, susu, shortening, air, garam disiapkan. Kemudian tepung terigu, tepung kelapa dan gula serta ragi dicampur sampai merata. Ditambahkan garam aduk kembali hingga rata selanjutnya ditambahkan telur dengan gula sambil dilakukan pengadukan, kemudian air dimasukkan sedikit demi sedikit sambil terus diaduk slanjutnya tambahkan garam dan susu. Setelah adonan agak lembut ditambahkan shortening/minyak sedikit demi sedikit sambil terus dilakukan pengadukan sampai adonan menjadi lembut. Dikeluarkan dari tempat pengadukan, adonan dibiarkan, tutup dengan plastik. Didiamkan selama 10 menit. Selanjutnya ditaburkan tepung terigu pada meja kerja. Adonan dituang ke meja kerja dan ditekan-tekan untuk mengeluarkan udara yang berlebihan. Kemudian dibagi sesuai peruntukan, sambil dipipihkan, dibuat bulat memanjang sesuai cetakan. Selanjutnya adonan dimasukan kedalam cetakan yang sudah diolesi dengan mentega dan tepung terigu biarkan selama 90 menit. Setelah adonan mengembang dimasukan dalam oven 
dengan suhu pembakaran $190-200{ }^{\circ} \mathrm{C}$, selama kurang lebih 30 menit. setelah masak didinginkan sebentar, kemudian masih dalam keadaan hangat dikeluarkan dari cetakan. Selanjutnya dalam keadaan dingin roti diiris-iris tipis-tipis dan dikemas dalam kantong plastik.

\section{Pengamatan}

Pengamatan dan analisis dilakukan pada roti meliputi : Daya kembang roti, kadar air (metode oven), kadar lemak (ekstraksi soxhlet), kadar protein (metode khedall), kadar karbohidrat (titrimetri), dan serat kasar (grafimetri) serta uji organoleptik (skala hedonik) terhadap penampakan, rasa, bau, warna dan tekstur.

\section{HASIL DAN PEMBAHASAN}

\section{Daya Kembang White Bread}

Hasil pengamatan perubahan sifat (berupa daya kembang) adonan pada berbagai tingkat persentasi tepung kelapa dengan tepung terigu dalam pembuatan white bread dapat dilihat pada Tabel 1. Dari Tabel 1 terlihat bahwa semakin tinggi persentasi penggunaan tepung kelapa, ekstensibilitas daya tahan adonan terhadap pengembangan makin berkurang. Hal ini dapat dilihat dari persentasi kenaikkan (pengembangan adonan) setelah adonan mengalami pemasakan. Pada penambahan $0,10,15,20,25 \%$ tepung kelapa, persentasi pengembangan adonan, berturut-turut $82,34 \%, 81,00 \%$, $79,72 \%, \quad 75,79 \%, 69,98 \%$. Hal ini disebabkan karena kandungan serat kasar yang tinggi pada tepung kelapa serta kadar air yang rendah $(3 \%)$ dan tidak adanya kandungan gluten pada tepung kelapa, mempengaruhi daya kembang adonan. Hal lainnya adalah tingkat kehalusan tepung kelapa yang jauh lebih rendah dari tepung terigu, mengakibatkan konsistensi adonan terhadap daya tahan pengembangan menjadi tidak sama. Ini berdampak pada tinggi adonan terhadap pengembangan.

Tabel 1. Perubahan daya kembang adonan pada berbagai tingkat persentasi tepung kelapa dalam pembuatan roti

\begin{tabular}{rccccc}
\hline $\begin{array}{c}\text { Tepung } \\
\text { kelapa } \\
(\%)\end{array}$ & $\begin{array}{c}\text { Berat } \\
\text { Adonan } \\
(\text { gram })\end{array}$ & $\begin{array}{c}\text { Tinggi } \\
\text { Adonan } \\
\text { Awal }(\mathrm{cm})\end{array}$ & $\begin{array}{c}\text { Tinggi adonan } \\
\text { sebelum } \\
\text { masak } \\
(\mathrm{cm})\end{array}$ & $\begin{array}{c}\text { Tinggi adonan } \\
\text { setelah masak } \\
(\mathrm{cm})\end{array}$ & $\begin{array}{c}\text { Pengembangan } \\
(\%)\end{array}$ \\
\hline 0 & 500 & 2.5 & 13.16 & 14.16 & 82.34 \\
10 & 500 & 2.5 & 12.33 & 13.16 & 81.00 \\
15 & 500 & 2.5 & 12.00 & 12.33 & 79.72 \\
20 & 500 & 2.5 & 10.66 & 10.33 & 75.79 \\
25 & 500 & 2.5 & 10.33 & 8.33 & 69.98 \\
\hline
\end{tabular}

Substitusi tepung kelapa terhadap tepung terigu menyebabkan penurunan kadar gluten dalam adonan, padahal gluten merupakan bahan yang mempunyai peranan penting dalam pengembangan adonan. Somaatmardjo (5) menyatakan bahwa gluten dari tepung terigu merupakan bagian terpenting. Gluten bersifat keras dan karena itu hardness dan softness dari tepung terigu ditentukan oleh 
kadar protein terbesar yang terdiri dari gluten. Gluten dapat menyebabkan roti mengembang dan porous-porousnya tetap kuat sehingga roti menjadi kekar, meskipun roti kekar tidak dikehendaki.

Penggunaan tepung kelapa 10 dan $15 \%$ menunjukkan prosentasi pengembangan yang cukup besar, dibandingkan dengan perlakuan prosentasi tepung kelapa lainnya. $\mathrm{Hal}$ ini menunjukkan penggunaan tepung kelapa sampai $15 \%$ merupakan toleransi untuk mendapatkan keseimbangan adonan mempertahankan daya kembang dalam pembuatan white bread. Penggunaan 20 dan $25 \%$ tepung kelapa menunjukkan daya kembang adonan setelah masak lebih rendah dari daya kembang adonan sebelum masak. Hal ini disebabkan karena kemampuan gluten memperangkap gas $\mathrm{CO}_{2}$ tidak mempunyai kekuatan yang cukup untuk mempertahankan gas setelah adanya pemanasan.

\section{Analisis Komposisi Kimia White Bread}

Data hasil analisis komposisi kimia white bread menggunakan tepung kelapa dapat dilihat pada Tabel 2.

Tabel 2. Hasil analisis white bread yang dibuat menggunakan tepung kelapa

\begin{tabular}{cccccc}
\hline $\begin{array}{c}\text { Perlakuan } \\
\text { tepung } \\
\text { kelapa }(\%)\end{array}$ & $\begin{array}{c}\text { Kadar Air } \\
(\%)\end{array}$ & $\begin{array}{c}\text { Kadar } \\
\text { Lemak } \\
(\%)\end{array}$ & $\begin{array}{c}\text { Kadar } \\
\text { Protein }(\%)\end{array}$ & $\begin{array}{c}\text { Karbohidrat } \\
(\%)\end{array}$ & $\begin{array}{c}\text { Serat Kasar } \\
(\%)\end{array}$ \\
\hline 0 & 32.75 & 5.76 & 8.965 & 40.10 & 0.81 \\
10 & 33.35 & 6.58 & 8.32 & 42.16 & 1.03 \\
15 & 32.73 & 6.71 & 8.54 & 38.84 & 1.33 \\
20 & 30.30 & 8.21 & 8.865 & 39.41 & 1.39 \\
25 & 31.29 & 9.16 & 8.935 & 36.64 & 1.79 \\
\hline
\end{tabular}

Dari hasil analisis kadar air (Tabel 2) terlihat bahwa semakin tinggi persentasi tepung kelapa terjadi kecenderungan penurunan kadar air. Hal ini disebabkan karena kadar air tepung kelapa rendah (3\%) sedangkan kadar air tepung terigu lebih tinggi dari tepung kelapa. Anonim, 2008 menyatakan bahwa kadar air tepung terigu 7,29\%. Kemampuan menyerap air tepung kelapa tidak sama dengan tepung terigu karena perbedaan kandungan pati. Kemampuan molekul-molekul pati dalam menyerap air berkurang diduga disebabkan gugus hidroksil antara tepung yang berbeda. Menurut Winarno (6), jumlah gugus hidroksil dalam molekul pati yang sangat besar menyebabkan kemampuannya menyerap air sangat besar.

Kadar lemak dari white bread yang dihasilkan (Tabel 2) terlihat bahwa semakin tinggi konsentrasi tepung kelapa semakin tinggi kadar lemak roti tawar. Hal ini disebabkan karena kandungan lemak tepung kelapa cukup tinggi. Lemak merupakan salah satu bahan pilihan yang digunakan, Somaatmadja (5) menyatakan bahwa lemak, terutama yang dijenuhkan 
(hydrogenated fat) seperti margarin, mempunyai pengaruh memperlunak gluten dan dengan demikian memperlunak roti yang dihasilkan.

Menurut Wijaya (7) menyatakan bahwa lemak merupakan bahan pilihan lain yang banyak digunakan. Lemak menambah citarasa roti, membuat roti lebih lembut, dan membantu pencoklatan roti menjadi lebih baik. Lemak membuat roti mengembang lebih besar tanpa memberi kesempatan gas $\mathrm{CO} 2$ terlepas sehingga roti mempunyai volume yang lebih besar.

Dari hasil analisis kadar protein dari white bread (Tabel 2) terlihat bahwa semakin tinggi konsentrasi tepung kelapa kadar protein yang dihasilkan tidak memberikan perbedaan yang berarti. Hal ini disebabkan karena kadar protein dan penggunaan tepung kelapa lebih kecil dibandingkan dengan kadar protein dan penggunaan tepung terigu. Tepung terigu yang digunakan dalam penelitian adalah tepung terigu cap gunung yang mempunyai kadar protein 13,0 persen. Tepung terigu dibedakan atas kandungan protein (kandungan glutennya). Kandungan gluten tepung terigu mempengaruhi hasil olahan, karena itu diperlukan jenis tepung terigu yang sesuai dalam pengolahan pangan berbasis terigu. Tepung terigu berprotein tinggi, kandungan proteinnya lebih besar dari $12,5 \%(8)$.

Hasil analisis kadar karbohidrat white bread (Tabel 2) menunjukkan bahwa semakin tinggi persentasi tepung kelapa, kadar karbohidrat roti tawar mengalami penurunan. Hal ini disebabkan karena tepung kelapa mengandung karbohidrat yang lebih rendah dari tepung terigu. Ada bermacam-macam roti, yang dibedakan atas dasar bahan penyusunnya. Namun secara umum roti dibedakan atas roti tawar dan roti manis. Kandungan gizi roti sangat ditentukan oleh bahan penyusunnya. Roti merupakan bahan makanan sumber karbohidrat, penganti nasi yang sangat potensial dan praktis untuk dikonsumsi (9).

Analisis kadar serat kasar white bread (Tabel 2) menunjukkan adanya peningkatan, seiring dengan pemberian tepung kelapa dalam jumlah yang lebih besar. Peningkatan kadar serat kasar, pada roti tawar berpengaruh terhadap daya kembang roti. Raghavendra dalam Meddiati (10) menyatakan bahwa kandungan serat kasar tepung ampas kelapa cukup tinggi yaitu 15,068 persen lebih tinggi dari tepung terigu 0,5\%. Kandungan serat pangan tak larut sangat tinggi yaitu $63,66 \%$ dan serat pangan larut sangat rendah 4,53\%. Almatsier mengemukakan bahwa ada dua macam golongan serat yaitu yang tidak dapat larut dalam air dan yang dapat larut dalam air. Serat yang tidak dapat larut dalam air adalah selulosa, hemiselulosa dan lignin. Serat yang dapat larut dalam air adalah pektin, gum, mucilage, glikan dan alga. Romulo N (11) menyatakan bahwa tepung kelapa mengandung serat kasar yang tinggi. Berkenan dengan aturan makan dapat digunakan sebagai suatu ramuan yang fungsional yang berguna bagi penurunan cholesterol serum dan index pengukuran glycemic.

\section{Pengujian Organoleptik}

$$
\text { Hasil pengujian organoleptik }
$$

berupa nilai sensorik terhadap rasa, warna, 
bau, penampakkan/ tekstur white bread dapat dilihat pada Tabel 3. Nilai skala hedonik yang digunakan ditunjukkan dengan angka 5 (sangat suka), 4 (suka) 3 (agak suka), 2 (tidak suka), 1(sangat tidak suka).

Tabel.3 Rasa, Warna, Bau, Penampakan dan tekstur white bread menggunakan tepung kelapa hasil penilaian panelis

\begin{tabular}{cccccc}
\hline $\begin{array}{c}\text { Perlakuan } \\
\text { Tepung } \\
\text { kelapa }(\%\end{array}$ & Rasa & Warna & Bau & Penampakkan & Tekstur \\
\hline 0 & 3,50 & 3,60 & 4,35 & 3,55 & 3,55 \\
10 & 3,80 & 4,10 & 3,80 & 3,90 & 3,70 \\
15 & 3,75 & 3,70 & 3,70 & 3,75 & 3,45 \\
20 & 3,45 & 3,70 & 3,65 & 3,60 & 3,55 \\
25 & 3,40 & 3,70 & 3,60 & 3,45 & 3,35 \\
\hline
\end{tabular}

Sebanyak 20 panelis telah berpartisipasi pada test organoleptic terhadap white bread yang terbuat dari campuran tepung terigu dan tepung kelapa. Dari Table 3. diatas memberikan informasi bahwa rata-rata panelis menyatakan dari segi rasa, warna dan bau penampakan/tekstur dari roti tawar, disukai panelis. Hal ini ditujukkan melalui rata-rata penilaian dengan kategori "suka" dari segi rasa dengan nilai $3,40-3,80$, warna $3,60-$ 4,10 , bau 3,60-4,35 dan penampakan 3,453,90, serta tekstur 3,35-3,70. Dengan kata lain produk roti tawar yang disubstitusi dengan tepung kelapa dapat diterima dengan baik oleh panelis.

\section{KESIMPULAN}

Semakin tinggi konsentrasi tepung kelapa terjadi penurunan kadar karbohidrat sedangkan kadar lemak, kadar serat kasar, kadar protein cenderung mengalami peningkatan dan dari pengujian organoleptik disukai panelis. Hasil terbaik
Dari kriteria rasa, perlakuan 10\% dan $15 \%$ yang banyak dipilih panelis, dari kriteria warna perlakuan $10-25 \%$ tepung kelapa yang banyak dipilih panelis. Dari kriteria bau perlakuan $10 \%$ dan $15 \%$ yang banyak dipilih panelis. Untuk kagetori penilaian penampakan dan tekstur perlakuan $10 \%$ yang banyak dipilih panelis. Dari kriteria rasa ,warna, bau, penampakan dan tekstur/pori-pori menunjukkan bahwa perlakuan penggunaan $10 \%$ dan $15 \%$ tepung kelapa masuk dalam kategori yang lebih banyak dipilih/disukai panelis. Dengan kata lain perlakuan penggunaan $10 \%$ dan $15 \%$ tepung kelapa dapat direkomendasikan untuk kegiatan produksi dalam pembuatan roti.

diperoleh pada perlakuan dengan menggunakan $10 \%$ tepung kelapa dilihat dari daya kembang, tingkat kesukaan panelis, bentuk/penampakan serta tekstur, sehingga dapat direkomendasikan dalam resep pembuatan white bread. 


\section{DAFTAR PUSTAKA}

1. Anonim. Sulawesi Utara Dalam Angka [Internet]. Biro Pusat Statistik Provinsi Sulawesi Utara; 2014. Available from: Regionalinvesment.bkpm.go.id/newipi d/commodilyarea.php?

2. Anonim. Pengembangan Peningkatan Mutu Tepung Kelapa Sesuai SII. Manado: Balai Penelitian Dan Pengembangan Industri Manado; 1992.

3. Ketaren S. Djdmiko. B. Daya Guna Hasil Kelapa. Departerment Teknologi Hasil Pertanian; 1978.

4. Rindengan, B., Lay, Novarianto MZ. Pengaruh Jenis dan Umur Buah Terhadap Sifat Fisiko Kimia Daging Buah Kelapa Hibrida dan Pemanfaatannya. J LITRI , Balai Penelit Kelapa dan Palma Lain Pus Penelit dan Pengemb Tanam Ind. 1996;Vol.1 Nomo.

5. Somaatmardjo. D. Pembuatan Roti. Bogor: Balai Penelitian Kimia Bogor; 1974.

6. Winarno. Kimia Pangan Dan Gizi. Jakarta: PT. Gramedia Pustaka Utama; 1991.
7. Wijaya H. Roti Pengganti Nasi Yang Praktis. Majalah Info Pangan. 1974;

8. Mengenal Bermacam-Macam Tepung [Internet]. [cited 2008 Feb 29]. Available from: http/ kamusdapurku. Blogspot. Com /2007/04

9. Keunggulan Gizi Roti Dibanding Beras [Internet]. [cited 2008 Feb 21]. Available from: http/groups.gougle.co.id /group/mahasiswa/browse thread /18.

10. Meddiati F.P. Kandungan Gizi Dan Sifat Fisik Tepung Ampas Kelapa Sebagai Bahan Pangan Sumber Serat [Internet]. 2010. Available from: http://jurnal.unnes.ac.id/index.php/tekn obuga/article/view/1176/50078

11. Romulo N Arancon Jr. Coconut Flour. Coco Info Int. 2005; Volume $6 \mathrm{~N}$. 